\title{
Study of Oral Acute Toxicity/Pathogenicity of the Tsukamurella Paurometabola Active Agent of the Biological Nematicide C-924 (Hebernem®)
}

\author{
Lizet Aldana Velazco ${ }^{1 *}$, Dania Bacardí Fernández ${ }^{1}$, Odette Beiro Castro ${ }^{2}$, Dra. Karelia Cosme ${ }^{1}$, Lic. Yamilka Ramírez Núñez ${ }^{3}$, Carmen \\ Valenzuela Silva1', Nelson Merino García ${ }^{4}$, Juan Fco. Sánchez de la Morena², Lic Lorelys Milá Cáceres', Téc. Rubén Amaya Izquierdo', Téc. \\ José Suárez Alba ${ }^{1}$, Onelio Carballo², Jesús Mena Campos ${ }^{3}$ and Carlos Borroto ${ }^{1}$
}

${ }^{1}$ Centro de Ingeniería Genética y Biotecnología (CIGB), Ave 31 \% 158 y 190, Cubanacán, Playa Habana, Cuba

${ }^{2}$ Centro Nacional de Toxicología (CENATOX), Habana, Cuba, Ave 31 y 114. Marianao, CP. 14020, Ciudad de la Habana, Cuba

${ }^{3}$ Centro de Ingeniería Genética y Biotecnología de Camaguey (CIGB-Cam.), Cuba. Circunvalación Norte y Avenida Finlay. Camaguey 70100. Cuba

${ }^{4}$ Centro de Investigaciones y Desarrollo de medicamentos, Habana, Cuba

\section{Summary}

The nematodes constitute one of the most phyto-pathogenic species in agriculture, using chemical and biological control agents. The Tsukamurella paurometabola is a bacterial strain with possibilities of being used as a nematicide; thus, it is necessary to evaluate the effect of its administration in lab animals with the objective of estimating its toxicity, infectivity and pathogenicity. To accomplish this aim, it was administered a single dose of $10^{8}$ ufc/animal with T. paurometabola C-924 in three variants as an active agent, final product (HEBERNEM®) and inactive final product by oral route to Sprague-Dawley rats of both sexes, and their respective placebos. The analyzed variables were: clinical observation, feed and water consumption, body weight, infectivity (tissues, organs and biological fluids), clearing or persistence (faeces collection) and gross and microscopic evaluations of interest organs. The obtained results showed that the administration of this microorganism in their three variants and their placebos, under our experimental conditions, didn't cause lethality neither influenced on weight, behavior and the physical state in the experimentation animals. The persistence showed that the microorganism was totally eliminated towards the day 15 of the study; likewise the infectivity determinations demonstrated the non-existence of colony formed units of the $T$. paurometabola in different times of samplings, resulting its inability to invade the guest's natural barriers, to infect it or to cause pathogenicity. The administration of the T. paurometabola, as an active agent and as final product, didn't cause signs, infective or pathogenic or toxic reactions in the experimentation animals.

Keywords: Toxicity/Pathogenicity/Infectivity; Biological Nematicide; Tsukamurella paurometabola

\section{Introduction}

In agriculture, the nematodes are one of the most phyto-pathogenic species and the most important plagues in the tropical, subtropical and temperate areas $[1,2]$. The losses caused by these organisms are estimated in 80 thousand million dollars annually worldwide [3-5].

During years, the use of a wide variety of nematicides [6], the resistance of plagues and insects to the chemical plaguicides action plus the problems of environmental contamination with marked negative influence on the beneficial organisms present in the soil [6] and health of birds and mammals, have led to the search and development of new ecological alternatives for the treatment of these agricultural plagues [7-17]. In this context, the development and agents of biological control application (BCA), acquires a relevant importance as a safety environmental alternative for handling plagues, since they are a natural component of the atmosphere and they are usually much more selective than chemical plaguicides $[15,18]$. According to data published, results of evaluations (publication indexes) and the experience gained in its use, the bio-plaguicides present a lower potential risk $[19,20]$.

Nevertheless, the introduction of any living organism in the atmosphere is often an irreversible step, for that reason, its assessment should be made complying with the regulatory and biosafety procedures established by international agencies, so that the organism doesn't become a plague by itself, or interfere with the natural process of other control plagues agents and/or cause toxicity in the species no-target, including the human being and other forms of life that cohabit in the atmosphere $[9,10,12,21,22]$.

In that case, once the potentialities of the microorganism are demonstrated like an agent to control plagues and before their inclusion in programs about biological control, it is obligatory to carry out a group of toxicological studies to determine safety for men, animals, plants and the atmosphere; with special emphasis on the studies of acute toxicity in mammals that constitute the initial stage of this evaluation.

In the Center of Genetic Engineering and Biotechnology of Camagüey, Cuba, several bacterial strains have been studied with possibilities of being employed as new biological nematicides; among them: the bacteria gram positive Tsukamurella paurometabola (Non ATCC 8368) [5,6,23], strain C-924, family Nocordiaceae of the genus Tsukamurella, identified initially as Corynebacterium paurometabolum

*Corresponding author: Lizet Aldana Velazco, Centro de Ingeniería Genética y Biotecnología (CIGB), Ave 31 \% 158 y 190, Cubanacán, Playa Habana, Cuba, Tel: (537) 2504306; Fax: (53-7) 2718070; E-mail: lizet.aldana@cigb.edu.cu

Received December 07, 2011; Accepted February 08, 2012; Published February 21, 2012

Citation: Velazco LA, Fernández DB, Castro OB, Cosme DK, Núñez LYR, et al. (2012) Study of Oral Acute Toxicity/Pathogenicity of the Tsukamurella Paurometabola Active Agent of the Biological Nematicide C-924 (Hebernem®). Adv Phar-

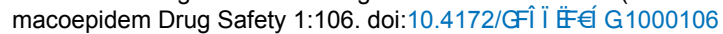

Copyright: (c) 2012 Velazco LA et al. This is an open-access article distributed under the terms of the Creative Commons Attribution License, which permits unrestricted use, distribution, and reproduction in any medium, provided the original author and source are credited. 
Citation: Velazco LA, Fernández DB, Castro OB, Cosme DK, Núñez LYR, et al. (2012) Study of Oral Acute Toxicity/Pathogenicity of the Tsukamurella Paurometabola Active Agent of the Biological Nematicide C-924 (Hebernem®). Adv Pharmacoepidem Drug Safety 1:106. doi:10.4172/

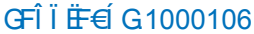

Page 2 of 6

[24] and later was classified as Tsukamurella paurometabola[23] characterized by their effectiveness and feasibility to be obtained at commercial scale.

This bacterium, forced aerobe, lightly curved $(0.5-0.8 \times 1.0-$ $5.0 \mathrm{~m}) \mathrm{can}$ be found in a simple form, even or masses. The colonies are small with convex elevation, frames smooth and easily emulsifies. These organisms through their metabolism produce hydrogen sulfide and chitinase [25], substances directly related with their nematicide effect. The effectiveness of its action mechanism depends also on the combination of effects caused in larvae and eggs weakening the external layer, constituted by $70 \%$ of chitin, originating vacuoles that cause disorder in the development of the nematodes. It is characterized to maintain their stability during several months, reducing gradually their presence until arriving at imperceptible levels [25], this aspect has to do with its effectiveness.

The T. paurometabola was isolated for the first time from ovaries of bedbugs (Cimex lecturalis) [25] and live in the environment involved in organic decomposition and the soil [26]. It is placed in group I of biological risk, classification of smaller infection risk to the human being, the community, according to the catalog of the bank NCIMB (Natural Collection of Industrial and Bacterial Marinates) [25].

The development reached in the studies of biological control agent, and before their inclusion in programs of biological control or field tests, made essential to carry out toxicological studies with HEBERNEM ${ }^{\circ}$, beginning with acute toxicity/pathogenicity in mammals, with the objective of estimating toxic events, infective and pathogenic effects, based on rules by the Office of Prevention, Plaguicides and Toxic Substances of the Environmental Protection Agency (EPA) from The United States involved in the Guides for the bioplaguicides toxicity evaluation (microbial) in mammals (EPA, 1996) [27-29].

From the results of the acute dermal toxicity/pathogenicity [30] tests and ocular irritation [31], in which the product tested, in its variants, didn't cause toxic effects in skin neither in the ocular structures of albino New Zealand rabbits, it was proceeded to estimate the toxic characteristics of the T. paurometabola after their oral administration in single dose to Sprague Dawley rats.

\section{Materials and Methods}

The study was carried out following the ethical norms described for the use of the experimentation animal [32], the Guides of Laboratory Good Practices [33,34] and the Standard Operation Procedures[35].

\section{Test system}

Adult albino rats, strain Cenp: Sprague Dawley [34,36,37], given by the National Center for Production of Laboratory Animals, CENPALAB, accompanied by Quality Certificate $[34,36]$. The animals were clinically examined, registering body weight and allocated in Makrolon boxes with wood sterile bed. They stayed in observation during 7 days, filling the adaptation period. The animals were daily fed with the formula EMO-1002 (ALYco, CENPALAB), giving 25grams per animal and ozonated water ad libitum.

A total of 178 animals, 89 females and 89 males were used, with 6 to 7 weeks of age and an average weight of $160.2 \mathrm{gr}$ for females and 187.3 gr, for males whose variation of weight didn't exceed the average value of $\pm 20 \%$ for both sexes.

\section{Animal husbandry}

The animals were kept under air condition environment, with the required conditions at $21 \pm 2^{\circ} \mathrm{C}$, relative humidity with a range between $60-70 \%$ and cycles of light-darkness of $12 \times 12$ [34,37,38]. There were fluctuation values of relative humidity, above the established range, without repercussions on the obtained results.

The cages of each experimental group were distributed in shelf racks in a way that the environmental factors were balanced to the maximum [35], allocated in Makrolon cages for sex and treatment groups as follows:

\section{Group I: 20 animals distributed individually/ cage T2.}

Group Ia: 8 animals (four females and four males) that belong to the autocontrol group (I a) used to assess the contamination in these animals due to coexistence with treated animals. The animals were allocated as follows:

1 animal per sex from the autocontrol group and group $\mathrm{V}$, remaining 2 female animals housed in one cage and the same way for male animals.

1 animal per sex from the autocontrol group and group VI, remaining 2 female animals housed in one cage and the same way for male animals.

The animals from groups II, III and IV were allocated individually in T2 cage, as shown in Table 1.

In group V: 26 animals were housed individually in T3 cage. The rest (4) were allocated as stated in the autocontrol group.

In group VI: 26 animals had individual housing in T3 cage. The rest (4) were allocated as explained in the autocontrol group.

\section{Formulation}

T. paurometabola was used Luria Bertani as culture medium (d, group V), final product composed of Tsukamurella paurometabola + torula yeast + xanthan gum (fp, group VI), their respective placebos Luria Bertani (dp, group II), and torula yeast + xanthan gum (ep, group III) and the inactivated final product HEBERNEM ${ }^{\star}$ subjected $1 \mathrm{~h}$ at $80^{\circ} \mathrm{C}$ (c, group IV), as shown in table 1 Annex.

\section{Experimental design}

The trial was designed complying with Plaguicides Microbial

\begin{tabular}{|l|l|l|}
\hline Group & Treatment & $\begin{array}{l}\text { Animals/group } \\
\text { (amount per sex })\end{array}$ \\
\hline I & Control Non treated & $\begin{array}{l}20 \\
(10 \text { female, } 10 \text { male })\end{array}$ \\
\hline Ia & Autocontrol & $\begin{array}{l}8 \\
(4 \text { female, } 4 \text { male })\end{array}$ \\
\hline II & Placebo 1 $(\mathrm{dp})^{\mathrm{a}}$ & $\begin{array}{l}30 \\
(15 \text { females, } 15 \text { males })\end{array}$ \\
\hline III & Placebo 2 $(\mathrm{ep})^{\mathrm{b}}$ & $\begin{array}{l}30 \\
(15 \text { females, } 15 \text { males })\end{array}$ \\
\hline IV & Inactivated final product $(\mathrm{c})^{\mathrm{c}}$ & $\begin{array}{l}30 \\
(15 \text { females, } 15 \text { males })\end{array}$ \\
\hline V & $\begin{array}{l}\text { T. paurometabola }+ \text { culture medium } \\
\text { Luria Bertani.(d) }\end{array}$ & $\begin{array}{l}30 \\
(15 \text { females, 15 males })\end{array}$ \\
\hline VI & Final product $(\mathrm{fp})^{\mathrm{e}}$ & $\begin{array}{l}30 \\
(15 \text { females, } 15 \text { males })\end{array}$ \\
& &
\end{tabular}

a culture medium Luria Bertani.

${ }^{\mathrm{b}}$ culture medium yest torula + gum xantano.

BioNem treated $1 \mathrm{~h}$ a $80^{\circ} \mathrm{C}$.

d. paurometabola. + culture medium Luria Bertani.

e T. paurometabola. + culture medium yest torula + gum xantano.

Table 1: Composition of the experimental groups. 
Guidelines of the Office of Prevention, Pesticides and Toxic Substances (OPPTS) of the Environmental Protection Agency (EPA) [27-29], including aspects described in the OECD Guide 425 [39]. The batch of animals was randomized following a list generated by the Aleator program and the raw was processed using SPSS Version 8.0 as statistical package $[40,41]$. The product was administered according to the international guidelines for evaluating products of biological origin [27-29], $10^{8} \mathrm{cfu} /$ animal doses, by oral route in fixed volumes [39]. The selected dose corresponds to 100 up times to the DLm for the control of the fitonematode in soil $\left(10^{6}\right.$ to $10^{7} \mathrm{cfu} / \mathrm{mL}$ of the final product solution) [25]. The food was retired previous to the product administration, keeping in mind the used route.

\section{Administration frequency}

It was carried out a single administration at the first day of the study by oral route using a metallic curved stem, in fixed volume of 1 product $\mathrm{mL}$ per animal [42]. The route selection was based on the previous toxicity evaluation to plaguicides from biological origin $[28,29]$ and the previous studies $[30,31]$

\section{Experimental groups}

The animals were distributed in six work groups: Group I, corresponding to the non treated control group, with 28 animals (14 per sex), in which 8 ( 4 females and 4 males) belonged to the autocontrol group (Ia), those that were placed together with animals treated with the product in the culture media (group V) and final product (VI), by sex, to measure possible transmission of the biological agent from an inoculated animal to a not inoculated. The rest of the five groups had 30 animals, 15 for each sex [29]. (Table 1 Annex)

\section{Duration of the test and observations}

After the administration of the product within 24 hours, the animals were observed at 3 and 6 hours. In additional days, the observation was carried out once a day to register changes in behavior and/or toxicity signs, skin, hair, eyes and mucous membranes, somatomotor activity and in the respiratory, circulatory and central nervous systems, for a period of 21 days for signs of delayed toxicity [29,35], according to the method of valuation described by Hayes and Pasquale [36].

Body weight of all the animals was registered individually before the administration and at the 24 and 72 hours in the animals sacrificed in these times. The rest of the animal mass was weighed with a weekly frequency. Water consumption and feed measurements were carried out daily for each animal, and in the case of rooming values were determined starting from the average consumption

\section{Evaluation of microorganism persistence}

To evaluate the persistence in the animals [29] of the T. paurometabola through the clearance, faeces collection were individually collected between 0.2 and $0.3 \mathrm{~g}$, at 24 and 72 hours from the autocontrol group and groups IV, $\mathrm{V}$ in those administered with the activated microorganism or not, after placing food and dose, and it was continued in a weekly frequency.

To quantify the microorganism a selective medium was used, in which the strain becomes a beige color determining contaminants when comparing them with the cfu of a universal medium. Later, the fecal feces cfu/grams were determined, in each treatment group and sex.

\section{Necropsy and histology study}

Prior to sacrifice, the animals were anesthetized with ethyl ether or ethoxyethane for narcosis then blood was extracted of the orbital plexus to determine the clearance in this biological fluid. The necropsy and sampling were conducted in compliance with the asepsis norms to ensure quality in the isolation of the microorganism to identify, for both in the intermediate and final sacrifice, registering the pathological changes observed to the organs macroscopic analysis [35].

The interest findings were fixed in buffered formaldehyde solution (10\%) during the first 24 hours and afterwards, a less concentrated solution (4\%) of the same substance was moved until it was embedded in paraffin, to cut and look under the microscope previously with hematoxylin-eosin staining [35].

The intermediate sacrifices were performed to assess infectivity and clearance in three animals/per sex at 24 and 72 hours after administering the product and one-week intervals after the dose for each experimental group.

\section{Evaluation of infectivity in organs, tissues and fluids}

The infectivity determinations, which allow valuing the microorganism capacity to reproduce in the host body, were carried out in the groups administered with the microorganism and in the animals of the autocontrol group in both, the intermediate sacrifices and finishing the trial [27-29]. Hence, it was individually listed the microorganism in liver, brain, kidney, lung, spleen, blood, oral mucous and thymus [29].

\section{Data Processing}

The variables used for the statistical treatment were body weight (BW), feed consumption (FC), water consumption (WC) and clearance (C). In the statistical analyses comparisons were carried out by group and sex, applying the tests of Shapiro-Wilk and of Levene, verifying the assumption normality and homogeneity of variances, respectively. Depending on the compliance, parametric analysis of variance (ANOVA) or not parametric analysis by Kruskal-Wallis were carried out. For each group, measures of central tendency and dispersion were calculated, as well as the maximum and minimum values and confidence interval of $95 \%$ for the average. The data processing was performed using the SSPS 8.0 program for Windows [41].

In the case of body weight, the mean body weight was calculated by group of treatment and sex $[29,35]$ with paired analysis comparing the increases at day 7 with the first day and the day 14 with day 7 .

With respect to FC and WC, the groups were compared at baseline and during 3 weeks of evaluation. At 7, 14 and 21 days, it was worked with average consumption of the week. The Wilcoxon test was used for paired analysis of the consecutive FC in each treatment group.

\section{Results}

\section{Clinical Observations}

The clinical observations of animals were performed daily, they didn't present toxic signs nor alterations in the behavior, maintaining somatomotor activity and response to stimuli according to the reported by the specie $[38,42-44]$. There were no reported changes in coat, color or appearance of the eyes and the mucous membranes were normal. No deaths were reported.

\section{Body weight and food consumption}

There was an adequate increase in body weight, corroborating the good health and lack of toxicity $(\mathrm{p}=0.01)$, results that agree with those 
Citation: Velazco LA, Fernández DB, Castro OB, Cosme DK, Núñez LYR, et al. (2012) Study of Oral Acute Toxicity/Pathogenicity of the Tsukamurella Paurometabola Active Agent of the Biological Nematicide C-924 (Hebernem®). Adv Pharmacoepidem Drug Safety 1:106. doi:10.4172/ 2167-1052.1000106

Page 4 of 6

\begin{tabular}{|l|l|l|l|l|}
\hline \multirow{2}{*}{ Group } & \multicolumn{4}{|c|}{ Day } \\
\cline { 2 - 5 } \multicolumn{1}{c|}{} & 1 & 8 & 15 & 22 \\
\hline I & $158.80 \pm 9.66$ & $181.83 \pm 13.99$ & $195.25 \pm 12.61$ & $195.50 \pm 7.78$ \\
\hline Ia & $153.25 \pm 9.50$ & $178.75 \pm 7.89$ & $188.75 \pm 10.31$ & $200.25 \pm 17.52$ \\
\hline II & $165.73 \pm 9.35$ & $192.50 \pm 12.76$ & $208.83 \pm 7.83$ & $222.67 \pm 9.07$ \\
\hline III & $163.53 \pm 9.36$ & $196.67 \pm 29.78$ & $198.33 \pm 10.48$ & $203.67 \pm 20.26$ \\
\hline IV & $161.27 \pm 9.97$ & $184.56 \pm 11.76$ & $196.00 \pm 13.02$ & $214.33 \pm 17.01$ \\
\hline V & $160.93 \pm 10.62$ & $191.78 \pm 11.70$ & $210.50 \pm 10.71$ & $224.00 \pm 16.37$ \\
\hline VI & $159.13 \pm 9.50$ & $188.00 \pm 13.26$ & $203.33 \pm 11.48$ & $218.67 \pm 12.06$ \\
\hline
\end{tabular}

Table 2: Female Body Weight (g).

\begin{tabular}{|l|l|l|l|l|}
\hline \multirow{2}{*}{ Group } & \multicolumn{4}{|c|}{ Day } \\
\cline { 2 - 5 } & 1 & 8 & 15 & 22 \\
\hline I & $182.10 \pm 20.17$ & $254.50 \pm 4.93$ & $289.25 \pm 8.73$ & $335.50 \pm 9.19$ \\
\hline Ia & $181.00 \pm 12.73$ & $242.50 \pm 26.04$ & $268.0 \pm 30.93$ & $321.25 \pm 56$ \\
\hline II & $183.47 \pm 17.52$ & $247.56 \pm 16.40$ & $269.67 \pm 19.04$ & $316.67 \pm 16.04$ \\
\hline III & $186.60 \pm 8.41$ & $239.56 \pm 9.41$ & $275.83 \pm 10.96$ & $314.67 \pm 9.07$ \\
\hline IV & $192.80 \pm 12.20$ & $250.67 \pm 7.11$ & $291.50 \pm 11.40$ & $340.00 \pm 6.00$ \\
\hline V & $192.40 \pm 10.78$ & $250.33 \pm 14.65$ & $287.00 \pm 21.06$ & $325.00 \pm 26.96$ \\
\hline VI & $188.93 \pm 10.31$ & $237.44 \pm 9.34$ & $278.67 \pm 8.94$ & $316.67 \pm 3.79$ \\
\hline
\end{tabular}

Table 3: Male Body Weight (g)

obtained in previous studies of dermal and eye irritability [30,31]. The increase on weight in each group was with no significant differences among them at each evaluation time from days $2,8,15$ and 22 as shown in Tables 2 and 3, according to that reported for this strain by IFFA CREDO[43] and Charles River Company[44].

At 24 and 72 hours, and 21 days of evaluation, the sample size per group ranged among 2-3 animals; thus mathematical comparisons between groups (not parametric) lacked power, giving the biological analysis a great value of the rest of the parameters evaluated as a whole.

\section{Food consumption (pelletized food and water)}

Food consumption was kept within the range of 17 to 23 grams for females and 24-25g for males [38]. The absence of significant variations in this parameter with the increase of body weight $(\mathrm{p}=0.01)$. In both sexes, there were homogeneous consumptions in times intervals considered. In females, significant decreases were detected in groups II, III, IV, V and during the first week and a significant increase in Group IV during the second week compared with the first day, resulting a low numeric magnitude in all cases, deserving a biological and combined evaluation of the other evaluated parameters. In male animals, significant variations of food consumption were not detected over time.

On the other hand, water consumption didn't show differences among groups in the intervals of time considered. In the paired analyses in each group, a significant decrease of the water consumption was detected during the first week of treatment compared to the initial consumption without evidence of relationship with the studied substance.

\section{Clearance}

Clearance of the T. paurometabola was 0 in Groups Ia and IV in both sexes. For the rest of the groups, a variable behavior was observed, making a difficult interpretation of the central tendency results. In both sexes, differences were detected among groups $(p<0.05)$ at all times with a clear tendency to a significant decrease in the occurrence of the cfu in the different moments of measurement.

It was determined that the products containing m.o in their formulation begins to be removed between 3 and 24 hours of being administered, observing a total clearance in the fecal feces at day 15 post-administration, considering that it is totally eliminated among day 8 and 15 of the study as shown in Tables 4 and 5.

T. paurometabola infectivity in tissues, organs and biological fluids, demonstrated the absence of cfu in the liver, brain, kidney, lung, spleen, blood, mucous oral and thymus.

Macroscopic evaluation of all animals showed the appearance of a finding in the animal number 14 of group $\mathrm{V}$, observing an increase in the spleen and liver. The histological treatment was carried out later, as it was explained in the paragraph based on necropsy, hyperplasia of the mononuclear phagocytic system; foci of necrosis and focal glanulomatous reaction were observed in both organs.

\section{Discussion}

The clinical observations lead to affirm its safety because there was no evidence of morphological and ethologic alterations in the system selected.

It is recognized the incidence and sensibility of body weight and food consumption for the detection of alterations due to exogenous substance administration, for this reason the sustained increase in body weight and food consumption with similar values to the reported for healthy animals of the species, constitute indirect values of non toxicity of the product in their different variants, as well as their placebos.

Zero values in the Tsukamurella paurometabola clearance in groups Ia and IV, is an expected result that demonstrated no contamination in animals housed together with those who were treated with the product in the culture medium and as final product, in addition, the absence of m.o, when the final product is inactivated without loss of its integrity evidences that the methodology used is effective, preventing the development of the unwanted strain and verifying the absence of harmful effects taken place in the animals, through other mechanisms like the anaphylaxis.

Although the cfu values were variable for the rest of the test groups, a tendency toward the significant decrease in measuring time could be corroborated.

The presence of cfu/g in feces values markedly larger in group VI than group $\mathrm{V}$ can related with each formulation using in every one. Both formulations are constituted by the test m.o, specific medium culture and in the final product find plus gum xantano, this establish the difference between those formulations (subtitle or heading Formulation, Table 1 Annex). The gum xantano is polysaccharides

\begin{tabular}{|l|l|l|l|l|l|l|}
\hline Group & $\begin{array}{l}3 \\
\text { horas }\end{array}$ & $1^{\text {st }}$ Day & $4^{\text {th }}$ day & $8^{\text {th }}$ day & $\begin{array}{l}15^{\text {th }} \\
\text { day }\end{array}$ & $\begin{array}{l}22^{\text {nd }} \\
\text { day }\end{array}$ \\
\hline la & $0 \pm 0$ & $0 \pm 0$ & $0 \pm 0$ & $0 \pm 0$ & $0 \pm 0$ & $0 \pm 0$ \\
\hline IV & $0 \pm 0$ & $0 \pm 0$ & $0 \pm 0$ & $0 \pm 0$ & $0 \pm 0$ & $0 \pm 0$ \\
\hline V & $0 \pm 0$ & $5793.33 \pm 2398.95$ & $1643.43 \pm 986.96$ & $326.13 \pm 281.92$ & $0 \pm 0$ & $0 \pm 0$ \\
\hline VI & $0 \pm 0$ & $20971.35 \pm 21485.40$ & $1021.41 \pm 1201.88$ & $152.36 \pm 110.74$ & $0 \pm 0$ & $0 \pm 0$ \\
\hline
\end{tabular}

Table 4: Levels of cfu/g in feces. Females.

\begin{tabular}{|c|c|c|c|c|c|c|}
\hline \multirow[t]{2}{*}{ Group } & \multirow{2}{*}{$\begin{array}{c}3 \\
\text { hours }\end{array}$} & \multicolumn{5}{|c|}{ Day } \\
\hline & & 1 & 4 & 8 & 15 & 22 \\
\hline la & $0 \pm 0$ & $0 \pm 0$ & $0 \pm 0$ & $0 \pm 0$ & $0 \pm 0$ & $0 \pm 0$ \\
\hline IV & $0 \pm 0$ & $0 \pm 0$ & $0 \pm 0$ & $0 \pm 0$ & $0 \pm 0$ & $0 \pm 0$ \\
\hline V & $0 \pm 0$ & $8679.76 \pm 5761.88$ & $2542.44 \pm 2092.43$ & $613.20 \pm 919.41$ & $0 \pm 0$ & $0 \pm 0$ \\
\hline VI & $0 \pm 0$ & $41620.00 \pm 14633.68$ & $981.69 \pm 1689.27$ & $212.19 \pm 181.33$ & $0 \pm 0$ & $0 \pm 0$ \\
\hline
\end{tabular}


Citation: Velazco LA, Fernández DB, Castro OB, Cosme DK, Núñez LYR, et al. (2012) Study of Oral Acute Toxicity/Pathogenicity of the Tsukamurella Paurometabola Active Agent of the Biological Nematicide C-924 (Hebernem®). Adv Pharmacoepidem Drug Safety 1:106. doi:10.4172/ 2167-1052.1000106

could be act as protector of the cellular wall because this is formulation stabilizer form $\mathrm{H} 2$ bridge links with the m.o in water absence getting stability and created a mechanism promotes the T. paurometabola rehydration while the Luria Bertani medium (group V) is not design for the m.o protection from the environment [45].

A total clearance was cheeked in the feces collection on day 15 of the study, which is another element to confirm the possibility to use this product when achieving faster clearance rates.

The microorganisms used for the biological control are important for their use as pathogens of plagues [46], so pathogenicity towards the target organism constitutes the wanted effect. However, this effect towards no-target organisms appears as undesirable, being the most important and controversial problem to the use of microbial pathogens as ACB [47]. Taking into account the before statement, the determination of non infectivity of the T.paurometabola in tissues, organs and biological fluids, evidenced that the microorganism was unable to invade or to cross the host natural barriers to infect or cause pathogenicity, what makes it a choice like ACB.

The observed macroscopic findings is characterized for its low frequency of occurrence, $1 / 178$, which makes us assume that is unrelated to the test item. The microscopic diagnosis, the hyperplasia related with the mononuclear phagocyte system, foci of necrosis and focal glanulomatous reaction presumably are given by a microsporidian infection possibly caused by Toxoplasma gondii in a single and proliferative form. This entity has been identified in the literature [48] as rat and mouse pathogen, like a hidden infection or current disease [49], as well as frequent association to cases of immune system depression [48]. The frequency of appearance from the reported signs, possible causes described in the literature for this species and the absence of m.o in organs, tissues and fluids analyzed in the infectivity determinations, result that the discoveries macro and microscopic are not related with the $T$. paurometabola administration, but with intrinsic characteristics of the animals observed.

\section{Conclusions}

The absence of toxic signs or changes in behavior, with somatomotor activity and respond to stimuli according to that reported, without affectations on the weight gain curve and an appropriate increase of body weight during the study, as well as food and water consumption value within the limits established for the used experimental species, showed lack of inherent toxicity to the Tsukamurella paurometabola. The total remove of the product at 15 days from the first administration was demonstrated, confirming not only the inability of the microorganism to invade the host natural barriers but also unable to cause pathogenicity, what allowed to conclude that the Tsukamurella paurometabola administration, as microorganism and as a final product, doesn't cause signs, pathogenic or infective toxic reactions in experimental animals at the tested dose.

\section{References}

1. Nickle WR (1991) Manual of agricultural nematology, New York.

2. Atkinson HJ BCPC Monograph No 65 (1993) Opportunities for Plant Molecular Biology in Crop Production. 257-266.

3. Handoo AZ (2001) Plant parasitic nematodes, a general article written for plan quarantine inspectors. Febrero.

4. Luc M, Hunt DJ, Sikora RA (1990) Reflections on Nematology in Sudtropical and Tropical Agriculture. En: Luc M, Hunt DJ, Sikora RA eds. Plant Parasitic Nematodes in Sudtropical and Tropical Agriculture. International Institute of Parasitology, CAB International Wallingford, 11-17.
5. Hidalgo $L$ (1999) Potencialidades de cepas autóctonas de V. chlamydosporium (Goddard) como agente de control biológico de Meloidogyne spp. La Habana. Tesis en opción al grado científico de Doctor en Ciencias Agrícolas. CENSAUNAH.

6. Hooper DJ, Evans K, Trudgill DL, Webster JM(1993) Plant Parasitic Nematodes in Temperate Agriculture. CAB International Wallingford, 48-59.

7. Rhodes DJ, Powell KA, Macqueen MP, Greaves MP (1990) Controlled delivery of biological control agents. Wilkins RM (Ed), En: Controlled Delivery of CropProtection Agents.

8. Glass DJ (1995) Biotic effects of soil microbial amendments. Rechcigl JE (Ed.) En: Soil amendments. Impacts on Biotic Systems. Lewis Publishers, CRC Press, Inc.

9. Lumsden RD, Lewis JA, Fravel DR (1995) Formulation and delivery of biocontrol agents for use against soilborne plant pathogens. Hall FR, Barry JW (Eds.) En: Biorational Pest Control Agents. Formulation and delivery. American Chemical Society, Washington, DC 595: 166-182.

10. Kerry BR, Kirkwood IA, de Leij FAAM, Barba J, Leijdens MB, et al. (1993) Growth and survival of Verticillium chlamydosporium goddard, a parasite of nematodes, in soil. Biocontrol Sci Technol 3: 355-365.

11. Stirling GR (1991) Biological Control of Plant Parasitic Nematodes: Progress Problems and Prospects. En: Stirling GR eds. Safety of Fungal Biocontrol Agents. CAB International, Wallingford UK, Page no. 374.

12. Wilson M, Backman PA (1999) Biological control of plant pathogens. Ruberson JR (Ed.). En: Handbook of Pest Management Marcel Dekker.

13. Rodriguez-Kabana R, Morgan-Jones G, Chet I (1987) Biological control of nematodes: soil amendments and microbial antagonists. Plant and Soil 100: 237-247.

14. Pinochet J, Calvet C, Camprubí A, Fernández C (1996) Interaction between migratory endoparasitic nematodes and arbuscular mycorrhizal fungi in perennial crops: a Review. Plant and Soil 185: 183-190.

15. Rodríguez-Kábana, Canullo GH (1992) Cropping systems for the management of phytonematodes. Phytoparasitica 20: 211-224.

16. De Liñán C (2001) Vademécum de productos fitosanitarios y nutricionales. Ediciones Agrotécnicas SL, Madrid, 670.

17. Lopez Llorca, Jansson LV, Hans B (2001) Biodiversidad del suelo: Contro Biológico de nematodos fitopatógenos por hongos nematófagos. Cuadernos de Bioversidad 6: 12-15.

18. Kerry B (1993) The use of microbial agents for the biological control of plant parasitic nematodes. DG Jones (Ed.), En: Explotation of Microorganisms. Chapman \& Hall, Londres 81-104.

19. Goettel MS, Johnson DL (1997) Safety and registration of microbial agents for control of grasshoppers and locusts. Memoirs of the Entomological Society of Canada 171: 83-99.

20. Estrada y MT (2012) López Los bioplaguicidas en la Agricultura Sostenible Cubana - Instituto de Investigaciones Fundamentales de Agricultura Tropical Alejandro de Humboldt" (INIFAT), C. de la Habana.

21. Hajek AE, Goettel MS (2007) Guidelines for evaluating effects of entomopathogens on non-target organisms. 816-833.

22. Boyetchko S, Pedersen E, Punja Z, Reddy M (1998) Formulations of Biopesticides. Hall FR \& Manr JJ Editores for Methods in Biotechnology, Vol 5, Page no: 487-508, Humana Press, Totowa, NJ.

23. Steinhaus EA (1941) A Study of the Bacteria Associated with Thrity Species of Insects. J.Bacteriol 42: 757-790.

24. Collins MD, Smida J, Dorsh M, Stackebrandt E (1988) Tsukamurella gen. nov harboring Corynebacterium paurometabolum and Rhodococcus aurantiacus. Int J Sist Bacteriol 38: 385-391.

25. Mena J Jefe del Proyecto Nematicida (1999) Información preliminar solicitada por el CENATOX sobre el "Bionematicida" para definir las pruebas que se efectuarán. CIGB Camagüey.

26. Euzeby JP (1998) Tazonomic note: necessary correction of specific and subspecific epithets according to Rules $12 \mathrm{c}$ and $13 \mathrm{~b}$ of the International Code of Nomenclature of Bacteria (1990 Revision). IJSEM 48: 1073- 1075.

27. Guías de Ensayo para Plaguicidas Microbianos 885.0001 de la Oficina de 
Citation: Velazco LA, Fernández DB, Castro OB, Cosme DK, Núñez LYR, et al. (2012) Study of Oral Acute Toxicity/Pathogenicity of the Tsukamurella Paurometabola Active Agent of the Biological Nematicide C-924 (Hebernem®). Adv Pharmacoepidem Drug Safety 1:106. doi:10.4172/ 2167-1052.1000106

Page 6 of 6

Prevención Plaguicidas y Sustancias Tóxicas OPPTS) (1996) Visión general de los Agentes Microbiológicos para el Control de Plagas. Agencia de Protección Ambiental (EPA) de los Estados Unidos.

28. Guías de Ensayo para Plaguicidas Microbianos 885.3000 de la Oficina de Prevención Plaguicidas y Sustancias Tóxicas (OPPTS) (1996) Bases de los Estudios de Toxicidad en Mamíferos, Patogenicidad e Infectividad. Agencia de Protección Ambiental (EPA) de los Estados Unidos.

29. Guías de Ensayo para Plaguicidas Microbianos 885.3050 de la Oficina de Prevención Plaguicidas y Sustancias Tóxicas (OPPTS) (1996) Toxicidad Oral Aguda/ Patogenicidad. Agencia de Protección Ambiental de los Estados Unidos.

30. Ensayo de Irritación Ocular del Corynebacterium paurometabolum, agente activo del nematicida biológico C-924. Código: IOCP0299.

31. Beiro O, García G, Carballo O, Ramírez Y, Valdivieso A, et al. (2006) A study of acute dermal toxicity for HeberNem in rats, Biotecnología Aplicada 23: 4345 .

32. Guidelines for Breeding and Care of Laboratory Animals (1998) World Health Organization and International Council for Laboratory Animals Science (ICLAS).

33. Food and Drug Administration (1997) Good Laboratory Practice for non clinical laboratory studies. Title 21 Code of Federal Regulations, Subchapter A, Part 58.

34. Cosme Díaz K (2007) Programa para el Uso de Animales de Experimentación del Centro de Ingeniería Genética y Biotecnología.

35. Procedimientos Patrones de Operación. Unidad Bioterio, CIGB.

36. Di Pasquale L, Hayes W (2001) Acute Toxicity and Eye Irritancy. In: Principles and Methods of Toxicology. Fourth Edition. pp 864-867. Taylor and Francis, Philadelphia, USA.

37. NRC. National (1997) Research Council. Animal Alternatives, Welfare and
Ethics, Edited by L.F.M van Zutphen and M. Balls. Developments in Animal and Veterinary Sciences, 27.

38. Canadian Council on Animal Care (1993) Guide for the care and use of experimental animals. Vol 1, Second edition Edited by Olfert ED, Cross BM and McWilliam AA.

39. OECD Guidelines for the Testing of Chemicals (2001) Acute Oral Toxicity, Modified Up-and-Down Procedure. Section 4: Health Effects.

40. Aleator I Randomization (computer software) (1997) Versión 1.1. Dpto. de Automatización. CIGB.

41. SPSS Inc (1997) Statistical Package Scientific Systems, versión 8.0, Windows

42. Animal Use and Toxicity Evaluation (1994) Victor S. and Lucas J. R. Ed. New York. Pp 29.

43. IFFA CREDO (1998) Laboratory Animals Technical Information, The OFA rat (Sprague/Dawley)

44. Charles River (1992) France Technical Information. Rat CD. Crl: CD (SD) BR.

45. Armando Hernández (2009) Anhydrobiotic cells of the nematocidic agent Tsukamurella paurometabola C-924 Biotecnología Aplicada 26: 4.

46. Cook RJ, Bruckart WL, Coulson JR, Goettel MS, Humber RA, et al. (1996) Safety of microorganisms intended for pest and plant disease control: a framework for scientific evaluation. Biological Control 7: 333-351.

47. Goettel MS, Hajek AE, Siegel JP, Evans HC (2001) Safety of fungal Biocontro Agents. En: Butt TM, Jackson C, Magan, N. eds. Fungi as Biocontrol Agents. CAB International Wallingford UK: 347-375.

48. Foulet A (1994) Pathology of Toxoplasma Gondii infetion in the nude rat. Path Res Pract 190: 775-781.

49. Cotchin E, Roe FJC (1967) Pathology of Laboratory rats and mice. Blackwel Scientific Publications, Oxford and Edinburg, Page no: 649-650. 